\title{
Spatial modelling of acute respitory infection with environmental health factors in Gowa Regency, Indonesia
}

\author{
Hadriani*1 $^{1}$, Andi Susilawati ${ }^{2}$, Emmi Bujawati ${ }^{3}$ \\ ${ }^{1,2}$ Bagian Kesehatan Lingkungan, Universitas Islam Negeri Alauddin, Makassar \\ ${ }_{3}^{3}$ Bagian Epidemiologi, Universitas Islam Negeri Alauddin, Makassar
}

DOI: $10.24252 / \mathrm{al}$-sihah.v12i2.15822

Received: 10 September 2020 / In Reviewed: 13 September 2020/ Accepted: 23 September 2020 / Available online: 28 September 2020 (C) The Authors 2020. This is an open access article under the CC BY-NC-SA 4.0 license

\begin{abstract}
Respiratory tract infections or ISPA is an infection that occurs in the nasal cavity, sinuses, and throat. ISPA is caused by influenza viruses, parainfluenza, and other typical viruses. The purpose of this study is to determine the spatial description of the environmental factor on ISPA disease in the working area of Gowa Regency, Indonesia. This research employs a quantitative research methodology by using a descriptive approach. The method used in this research was a spatial pattern. The research results showed that the spread of ISPA disease could be restrained based on several measurements. It reveals that the ventilation area of the respondent's house was $66.3 \%$ in which it did not meet the proper ventilation standards; the type of the wall used in the respondent's house was $25.0 \%$ which did not meet the proper wall standard; the type of floor used in the respondent's house was $31.3 \%$ which did not meet the proper floor standard; the density of the respondent's house was $31.3 \%$ in which the occupancy density did not meet the proper density standard; the room temperature of the respondent's house was $27.5 \%$ which did not meet the proper temperature standard, and lastly the spread of ISPA disease based on the humidity of the respondent's room was $32.5 \%$ which means that the room humidity did not meet the proper humidity standard. Based on the research results, it is expected that a clear understanding of the importance of maintaining a clean home environment could be gained.
\end{abstract}

Keywords: acute respiratory; infection; ispa; spatial, ventilation;

\begin{abstract}
ABSTRAK
Infeksi saluran pada pernapasan akut atau ISPA adalah infeksi yang pada umumnya terjadi pada rongga hidung, daerah sinus serta tenggorokan. ISPA disebabkan oleh virus influenza, parainfluenza, dan lain sebagainya. Tujuan penelitian ini adalah untuk mengetahui gambaran spasial faktor lingkungan penyakit ISPA di Kabupaten Gowa, Indonesia. Jenis penelitian yang digunakan adalah penelitian kuantitatif dengan menggunakan pendekatan deskriptif. Metode yang digunakan adalah pola spasial. Hasil penelitian menunjukkan bahwa penyebaran penyakit ISPA berdasarkan luas ventilasi rumah responden $(66.3 \%)$ dengan ventilasi rumah yang tidak memenuhi syarat, jenis dinding rumah responden $(25.0 \%)$, memiliki jenis dinding rumah yang tidak memenuhi syarat, jenis lantai rumah responden $(31.3 \%)$ memiliki jenis lantai rumah yang tidak memenuhi syarat, kepadatan hunian responden $(31.3 \%)$ memiliki kepadatan hunian yang tidak memenuhi syarat, berdasarkan suhu ruangan rumah responden $(27.5 \%)$ dengan suhu ruangan yang tidak memenuhi syarat, dan penyebaran penyakit ISPA berdasarkan kelembaban ruangan rumah responden $(32.5 \%)$ memiliki suhu ruangan yang tidak dalam suhu baik. Hasil penelitian ini memberikan gambaran peta secara spasial mengenai faktor risiko ISPA yang dibutuhkan pihak kesehatan dalam melakukan upaya penanggulangan.
\end{abstract}

Kata Kunci : infeksi; ispa; pernafasan akut; spasial; ventilasi

*Alamat Korespondensi:

Jl. Poros Pinrang-Langnga, Desa Bunga, Kec. Mattiro Bulu, Pinrang

Email: hadrianiani4@gmail.com 


\section{PENDAHULUAN}

Infeksi saluran pernapasan akut (ISPA) selalu menjadi masalah kesehatan pada manusia yang secara global diakui sebagai penyebab utama mortalitas dan morbiditas di antara anak balita (Adesanya \& Chiao, 2016). ISPA terus menjadi penyumbang angka kesakitan terbesar di antara anak-anak, dan bertanggung jawab atas sekitar $70 \%$ morbiditas balita di negara berkembang (Selvaraj et al., 2014) Penyakit ini menjadi penyebab paling umum kematian anak berusia di bawah 5 tahun di seluruh dunia (Liu et al., 2016).

Infeksi saluran pernapasan akut terdiri dari infeksi saluran pernapasan bagian atas dan saluran pernapasan bagian bawah. Infeksi saluran pernafasan atas paling sering disebabkan oleh virus, berhubungan dengan infeksi pada laring, termasuk rinitis (flu biasa), sinusitis, infeksi telinga, faringitis akut, epiglotitis dan radang tenggorokan. Infeksi saluran pernafasan bagian bawah terdiri dari infeksi bakteri atau virus yang terjadi di bawah laring yang meliputi bronkitis, bronkiolitis, dan pneumonia (Simoes et al., 2004). Secara khusus, pneumonia bertanggung jawab atas sekitar 1,41,8 juta kasus fatal pada anak di bawah usia lima tahun secara global (Bakalets, 2017). Selain itu infeksi saluran pernafasan akut pada beberapa kasus juga mampu mengakibatkan komplikasi pada jantung (Davidson
\& Warren-Gash, 2019).

Pada tahun 2010, ada sekitar 120 juta kasus dan 1,3 juta kematian terkait pneumonia di seluruh dunia, dan sebagian besar terjadi di Asia Tenggara dan Afrika subSahara (Walker et al., 2013). Di negara berpenghasilan rendah dan menengah, ISPA pada anak berusia $<5$ tahun umumnya lebih parah daripada pada anak yang lebih tua dan dewasa serta menghasilkan kasus kematian yang lebih tinggi daripada di negara-negara yang berpenghasilan tinggi (Kyu et al., 2013). Faktor risiko ISPA dapat dibagi menjadi dua kelompok yaitu faktor internal dan eksternal. Faktor internal yaitu kondisi dalam diri pasien yang membuat individu lebih mudah terpapar agen penyakit ISPA yang meliputi jenis kelamin (Musa et al., 2016), berat badan lahir (Chandrawati \& Alhabsyi, 2017), status menyusui (Narmawan et al., 2020), dan status imunisasi (Khodr et al., 2017). Faktor eksternal adalah kondisi yang berada di luar pasien berupa lingkungan fisik (Barros \& Yudhana, 2019), biologis (Kurskaya, et al., 2018), sosial (Harerimana, 2016), dan ekonomi (Halder et al., 2017) yang memudahkan mereka terpapar agen penyakit, antara lain: pencemaran asap rokok (Tazinya et al., 2018), kebersihan rumah (Ratnaningsih \& Lusiana, 2020), kepadatan tempat tinggal (Nugroho, 2018), kondisi geografis (Barnes et al., 2019), kondisi ven- 
tilasi (Zhu et al., 2020), lubang asap dapur serta kondisi ruang tidur (Zulaikhah et al., 2017).

Penyakit ISPA dalam beberapa tahun terakhir terus menjadi masalah kesehatan utama di Indonesia, prevalensi ISPA di Indonesia pada tahun 2018 adalah 4,4\% dengan total kasus sebanyak 1.017.290 kasus. Kelompok umur 1-4 tahun sebesar $2,0 \%$ dan $<1$ tahun sebesar $4,0 \%$ adalah kelompok umur dengan prevalensi ISPA yang tertinggi (Kementerian Kesehatan RI, 2019a). Di Sulawesi Selatan Prevalensi Kejadian ISPA menurut hasil diagnosis dari tenaga kesehatan pada tahun 2018 yaitu sebesar $1,85 \%$ dengan kelompok umur tertinggi berada pada usia 1-4 tahun dan 65 -74 tahun. Adapun prevalensi ISPA di Kabupaten Gowa yaitu sebesar $0,8 \%$ dengan total kasus sebanyak 4339 kasus (Kementerian Kesehatan RI, 2019b).

Berdasarkan hasil survei kasus ISPA di seluruh wilayah kerja Puskesmas Kabupaten Gowa sebesar 8,68\% cakupan penemuan penderita pada tahun 2017. Dan mengalami peningkatan pada tahun 2018 menjadi $156,47 \%$ penderita. Kasus ISPA di wilayah kerja Puskesmas Somba Opu semua umur yaitu $19,47 \%$ dan selalu menjadi urutan pertama dari 10 penyakit terbanyak yang terjadi di wilayah kerja Puskesmas Somba Opu.

Dengan kemajuan ilmu pengetahuan dalam hal teknologi GIS, berbagai teknik pemodelan spasial telah dikembangkan dan diterapkan untuk mengevaluasi permasalahan lingkungan belakangan ini. GIS dan pengindraan jauh dapat digunakan untuk merinci area yang lebih luas dengan cara yang lebih hemat biaya (Kim et al., 2019). Metode ini juga memungkinkan pelacakan kontak spasial dari kasus yang dicurigai, prediksi spasial penularan penyakit dan pemetaan risiko untuk memahami epidemiologi penyakit (Devasia et al., 2020).

Keterpaparan informasi melalui SIG dapat dimanfaatkan oleh Puskesmas untuk memperoleh informasi dan memberikan informasi kepada masyarakat mengenai sebaran daerah rawan. SIG adalah sistem pencitraan informasi kesehatan yang dapat menggambarkan informasi spasial tentang suatu keadaan tertentu seperti faktor risiko penyakit sehingga dapat membantu pengambilan keputusan. Oleh karena itu, penelitian ini menggabungkan informasi dari ilmu teknik dan kesehatan untuk membuat peta penyakit dengan memanfaatkan fungsionalitas SIG.

Beberapa puskesmas di Kabupaten Gowa mengolah data sebaran faktor risiko ISPA dan angka kejadian ISPA dan secara manual yang masih terbatas dalam bentuk tabel. Oleh karena itu dibutuhkan teknologi pemetaan untuk mengidentifikasi faktor risiko, peta kasus, dan peta kegiatan 
lainnya, yang pada akhirnya membantu memandu intervensi untuk mencegah ISPA dan mengurangi kejadian kasus. Berdasarkan uraian di atas, maka tujuan penelitian ini adalah membuat peta sebaran kasus infeksi saluran pernafasan akut berdasarkan faktor kesehatan lingkungan di Kabupaten Gowa didiagnosa selama 3 bulan terakhir di ruang lingkup kerja Puskesmas Somba Opu Kabupaten Gowa Provinsi Sulawesi Selatan pada bulan Januari-Mei tahun 2019 berjumlah 80 penderita. Sampel dalam penelitian ini adalah seluruh data populasi (total sampling) yang berjumlah 80 orang. Dalam penelitian ini peneliti menggunakan instrumen denah

Tabel 1. Distribusi Karakteristik Responden

\begin{tabular}{lcc}
\hline \multicolumn{1}{c}{ Distribusi Responden } & Jumlah & Persentasi \\
\hline Usia & 6 & \\
$1-8$ & 10 & 7.5 \\
$9-16$ & 25 & 12.5 \\
$17-24$ & 20 & 31.25 \\
$25-32$ & 12 & 25 \\
$33-40$ & 6 & 15 \\
$41-48$ & 1 & 7.5 \\
$57-64$ & & 1.25 \\
Jenis Kelamin & 24 & 30 \\
Laki-Laki & 56 & 70 \\
Perempuan & & \\
Kelurahan & 27 & 33.75 \\
Bonto-bontoa & 13 & 16.25 \\
Sungguminasa & 11 & 13.75 \\
Katangka & 7 & 8.75 \\
Batangkaluku & 7 & 8.75 \\
Kalegowa & 6 & 7.5 \\
Pandang-pandang & 5 & 6.25 \\
Tombolo & 4 & 5 \\
Tompobolo & & \\
\hline
\end{tabular}

Sumber: Data Primer, 2019

\section{METODE PENELITIAN}

Jenis penelitian ini merupakan studi kuantitatif dengan pendekatan deskriptif. Metode yang digunakan adalah gambaran spasial. Lokasi penelitian terletak di wilayah kerja Puskesmas Somba Opu Kabupaten Gowa. Populasi dalam penelitian ini adalah seluruh penderita ISPA yang pernah wilayah serta perangkat Global Positioning System (GPS) Garmin etrex 10, tabel koesioner serta alat pengukuran suhu dan kelembaban. Untuk penyesuaian standar maka dilakukan kalibrasi pada alat sebelum digunakan. Setelah data dikumpulkan yang berupa beberapa titik koordinat rumah yang menjadi sampel penelitian selanjutnya dil- 
akukan olah data menggunakan beberapa software pengelola data khusus spasial. Studi ini dilakukan dengan memanfaatkan softwere Quantum GIS Liboa versi 1.8.0 dan Mapsource dan GPS tipe Garmin etrex 10. Penelitian ini mengambil 80 titik dengan menggunakan GIS kemudian di analisis menggunakan aplikasi Quantum

\section{HASIL PENELITIAN}

Berdasarkan tabel 1 menunjukkan distribusi responden terkait identitas dengan kategori umur yang terbanyak berada pada umur 17-24 tahun sebanyak 25 jiwa ( $31.3 \%$ ), untuk kategori jenis kelamin yang terbanyak adalah berjenis kelamin perempuan sebanyak 56 jiwa ( $70.0 \%)$,

Tabel 2. Distribusi Responden Berdasarkan Kondisi Fisik Lingkungan

\begin{tabular}{lcc}
\hline \multicolumn{1}{c}{ Kategori } & Jumlah & Persentasi \\
\hline Luas Ventilasi & & \\
Memenuhi Syarat & 27 & 33.75 \\
Tidak Memenuhi Syarat & 53 & 66.25 \\
Jenis Dinding & & \\
Memenuhi Syarat & 60 & 75 \\
Tidak Memenuhi Syarat & 20 & 25 \\
Jenis Lantai & & \\
Memenuhi Syarat & 55 & 68.75 \\
Tidak Memenuhi Syarat & 25 & 31.25 \\
Kepadatan Hunian & & 68.75 \\
Memenuhi Syarat & 55 & 31.25 \\
Tidak Memenuhi Syarat & 25 & 68.75 \\
Suhu & & 27.5 \\
Memenuhi Syarat & 55 & 67.5 \\
Tidak Memenuhi Syarat & 22 & 32.5 \\
Kelembaban & & \\
Memenuhi Syarat & 54 & \\
Tidak Memenuhi Syarat & 26 & \\
\hline
\end{tabular}

Sumber: Data Primer, 2019

GIS pada wilayah kerja Puskesmas Somba Opu. Terdiri dari beberapa kelurahan diantaranya Kelurahan Sungguminasa, Kelurahan Batangkaluku, Kelurahan Bontobontoa, Kelurahan Katangka, Kelurahan Pandang-pandang, Kelurahan Tompobalang, Kelurahan Kalegowa, dan Kelurahan Tombolo, dan kategori alamat yang terbanyak adalah Bonto-bontoa dengan frekuensi 27 rumah $(33.8 \%)$

Berdasarkan tabel 2 menunjukkan sebaran penyakit ISPA berdasarkan luas ventilasi kategori tidak memenuhi syarat dengan jumlah $53(66,3 \%)$, jenis lantai rumah responden dengan kategori tidak memenuhi syarat dengan jumlah 25 (31.5\%), jenis dinding rumah responden dengan kat- 


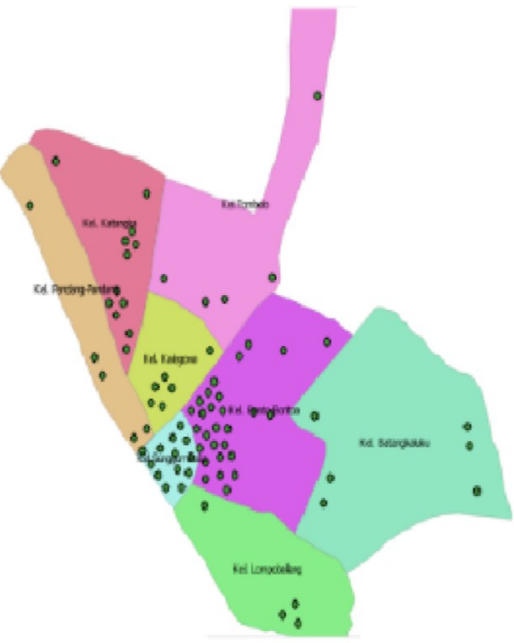

(a)

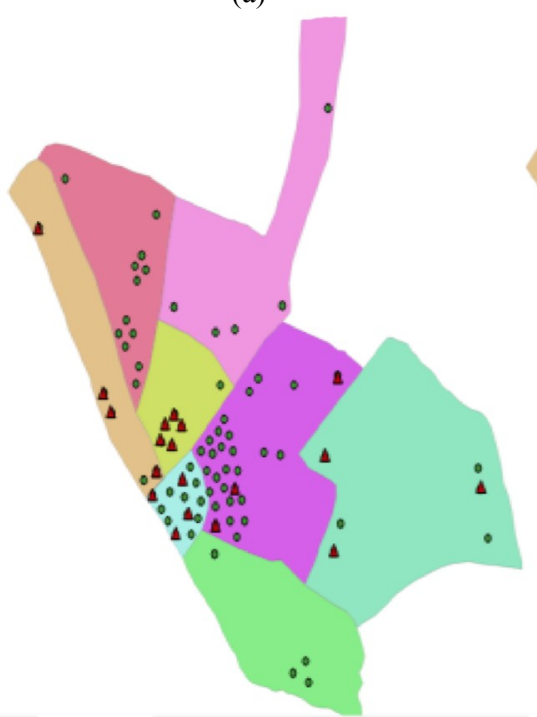

(d)

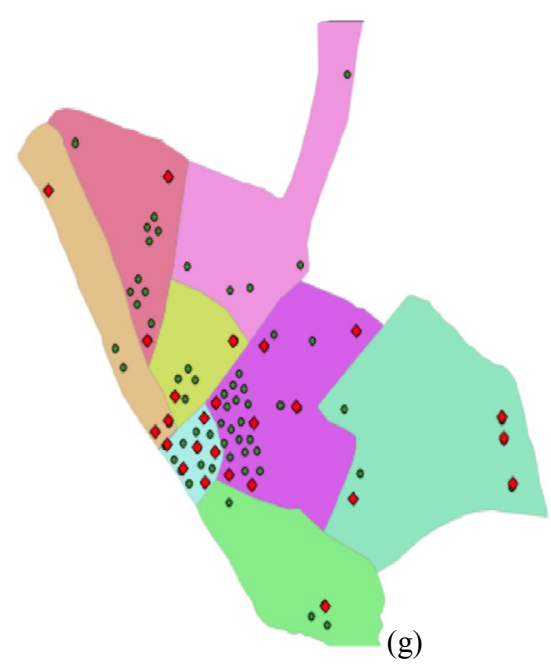

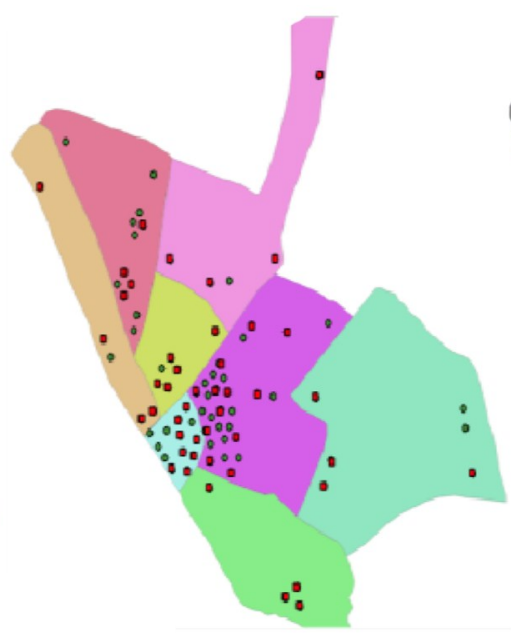

(b)

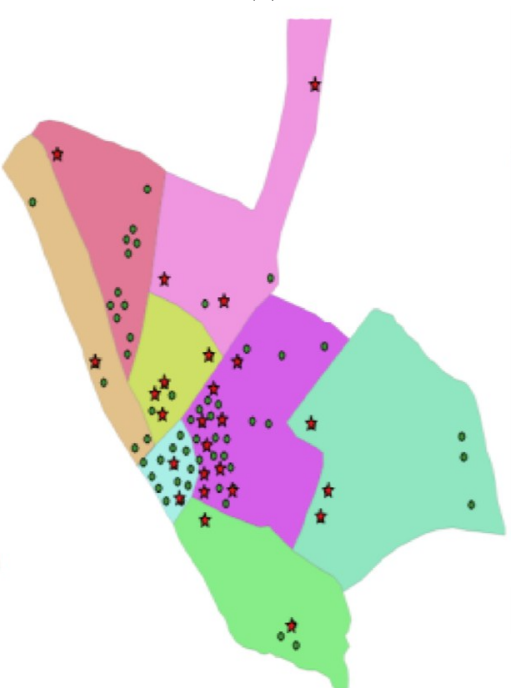

(e)

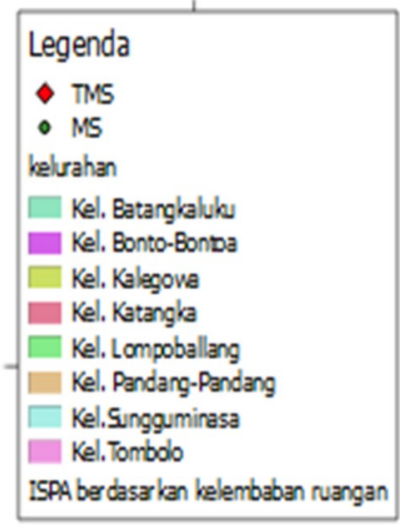

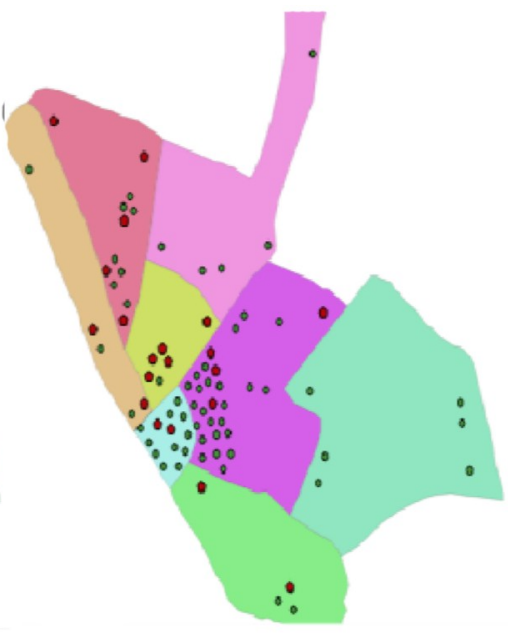

(c)

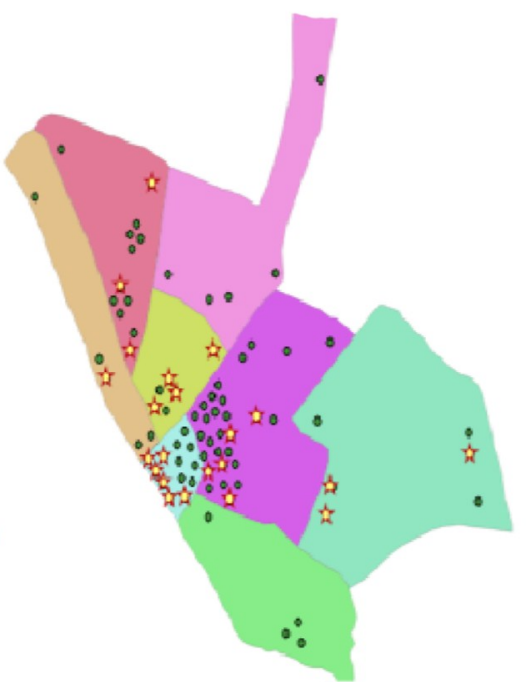

(f)

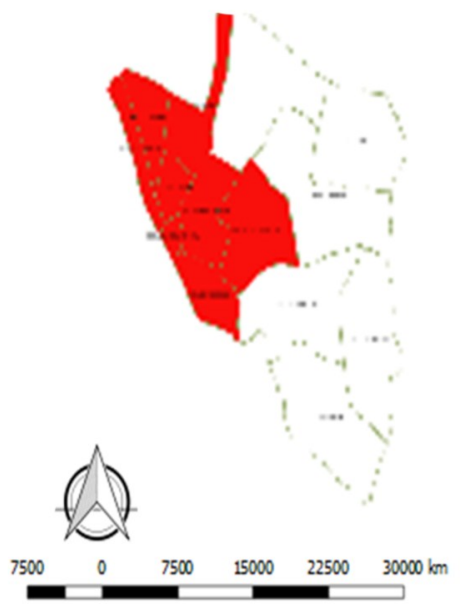

Gambar 1. Sebaran Penyakit ISPA dengan: a) Kondisi Fisik Rumah, b) Luas Ventilasi, c) Jenis Lantai, d) Jenis Dinding, e) Kepadatan Hunian, f) Suhu Ruang, g) Kelembaban 
egori tidak memenuhi syarat dengan jumlah 20 (25.0\%), kategori tidak memenuhi syarat dengan jumlah 25 (31.5\%), kondisi suhu rumah responden dengan kategori tidak memenuhi syarat dengan jumlah 22 (27.5\%), dan kelembaban rumah responden dengan kategori tidak memenuhi syarat dengan jumlah 26 (32.5\%),

Pada gambar 1 menunjukkan sebaran penyakit ISPA menurut kondisi fisik rumah, luas ventilasi, jenis dinding, kepadatan hunian, suhu ruang dan kelembapan yang tersebar di 8 kelurahan di Kabupaten Gowa. Pada gambar ini kondisi lingkungan rumah yang memenuhi syarat ditandai dengan titik berwarna hijau sedangkan titik berwarna merah adalah kondisi yang tidak memenuhi syarat.

\section{PEMBAHASAN}

Penelitian yang telah dilakukan menunjukkan bahwa ventilasi rumah responden sebagian besar responden tidak memenuhi syarat. Beberapa responden menyatakan bahwa ventilasi mereka jarang dibuka dan masih banyak ventilasi responden bersifat permanen seperti kaca. Sehingga menghambat terjadinya proses sirkulasi udara pada rumah. Ventilasi sangat bermanfaat dalam menganggati udara dari dalam rumah secara kontinuitas dengan udara dari luar rumah, sehingga perkembangan bakteri atau virus penyebab penyakit ISPA dapat dicegah. Ventilasi dalam kondisi buruk dapat menjadi penyebab terjadinya kelembaban tinggi serta menjadi faktor risiko timbulnya bibit penyakit seperti ISPA (Neto et al., 2016).

Hal ini sejalan dengan penelitian yang dilakukan Mayasari (2017) pada responden di Kota Wilayah Utara Kota Kediri yang memaparkan bahwa sebagian besar responden memiliki ventilasi rumah jauh dari standar kesehatan perumahan yaitu 63,7\%). Faktor ventilasi menjadi faktor utama penyebab terjadinya ISPA di mana nilai $\operatorname{Exp(B)~0,014~lebih~banyak~dibandingkan~}$ nilai $\operatorname{Exp}(\mathrm{B})$ kedua faktor lainnya yaitu $\mathrm{Ba}-$ han Bangunan 0,012 dan lantai 0,010 terhadap kejadian ISPA. Berdasarkan hasil observasi, ventilasi rumah cenderung hanya di bagian depan rumah saja karena di bagian samping sudah tertutupi oleh tembok bangunan rumah. Selain itu penelitian dengan pendekatan case-control yang dilakukan oleh Admasie et al. (2018) juga menemukan bahwa anak di Wolaita-Sodo, Ethiopia Selatan yang tinggal di rumah dengan kondisi ventilasi yang buruk berisiko tinggi terkena penyakit saluran pernafasan akut.

Pada penelitian ini, lantai rumah responden yang diobservasi rata-rata berupa lantai tanah dan semen, sehingga sewaktuwaktu dapat menyimpan debu. Lantai yang terbuat dari semen rata-rata mudah men- 
galami kerusakan serta tidak kedap air, pada akhirnya akan menyebabkan berdebu dan lembap. Lantai yang dianjurkan harus dapat menjaga kelembaban, tidak kedap air, serta mudah dibersihkan.

Hasil penelitian ini sejalan dengan temuan Suabey (2020) yang melakukan penelitian observasional dengan pendekatan cross-sectional di Kabupaten Jayawijaya tepatnya di Kampung Anelak Distrik Siepkosi. Hasil penelitian menunjukkan bahwa sebagian responden memiliki lantai rumah tidak baik (75,8\%). Hasil analisis data dengan uji chi-squere memaparkan bahwa ada hubungan yang cukup kuat antara sanitasi fisik rumah yang salah satunya keadaan lantai rumah dengan kejadian infeksi saluran pernafasan akut pada masyarakat di daerah tersebut. Selain itu penelitian yang dilakukan oleh Mahendra \& Farapti (2018) juga menemukan bahwa terdapat hubungan kondisi fisik rumah seperti jenis lantai yang digunakan dengan terjadinya penyakit ISPA pada anak di Surabaya.

Keberadaan dinding rumah bermanfaat untuk mempertahankan suhu dalam ruangan serta menjadi penyangga atap yang menjadi pelindung rumah dari angin, panas serta gangguan vektor. Dinding yang memenuhi syarat adalah yang terbuat dari bata, bersifat permanen, kokoh, tidak berlubang dan kedap air. Keberadaan dinding ini akan mencegah naiknya kelembaban dari tanah.
Dinding yang terbuat dari anyaman bambu dapat tahan terhadap segala kondisi cuaca dan baik digunakan pada daerah yang rawan polusi seperti pedesaan, tetapi tidak permanen, mudah roboh, tidak dapat menahan lembap serta berpotensi untuk terbakar. Kebersihan dan kerapatan dinding akan menurunkan risiko terjadinya infeksi pernafasan akibat polutan (Okari, 2019).

Hasil menunjukkan bahwa $25.0 \%$ rumah responden memiliki jenis dinding rumah yang tidak memenuhi syarat dan $75.0 \%$ rumah responden memiliki jenis dinding rumah yang memenuhi syarat yang ditentukan apabila dinding rumah permanen dan terbuat dari tembok. Berdasarkan hasil observasi, jenis dinding rumah sebagian rumah memenuhi syarat yakni memiliki dinding rumah yang terbuat dari tembok. Hal ini berbeda dengan penelitian yang dilakukan oleh Putri \& Mantu (2016) di Kecamatan Ciwandan Kota Cilegon. Hasil peneltian dengan desain cross-sectional ini menunjukkan hubungan yang bermakna antara kondisi dinding fisik rumah dengan kejadian ISPA pada balita. Penelitian lain dari Padmonobo et al. (2012) menunjukkan bahwa ada korelasi antara kejadian penyakit infeksi saluran pernafasan pada balita dengan tipe dindingnya di wilayah kerja Puskesmas Jatibarang Kabupaten.

Penyakit infeksi pernafasan merupakan penyakit yang bersumber dari mikroor- 
ganisme atau polutan yang menginfeksi manusia melalui media udara, oleh karena itu, terjadinya penyakit infeksi pernafasan dapat diakibatkan karena kepadatan hunian. Rumah dengan jumlah anggota keluarga yang tinggi akan mengakibatkan sirkulasi dan proses pertukaran udara lebih rendah, juga akan berdampak pada tubuh orang yang sehat yang gampang tertukar penyakit jika ada salah satu anggota keluarga yang sakit, karena penularan penyakit ISPA akan lebih cepat apabila terjadi pengumpulan massa. Luas ruang tidur sebaiknya minimal 8 meter per penghuni, dan demi menjaga kesehatan psikologis penghuni rumah maka tidak dianjurkan digunakan lebih dari 2 orang tidur untuk satu ruang tidur, kecuali untuk anak di bawah umur 5 tahun.

Hasil menunjukkan bahwa (68.8\%) rumah responden memiliki kepadatan hunian yang memenuhi syarat dan (31.3\%) rumah responden memiliki kepadatan hunian yang tidak memenuhi syarat yang ditentukan apabila sekat antara ruangan dalam rumah dengan luas $5 \mathrm{~m}^{2}$ per orang. Berdasarkan hasil observasi, kepadatan hunian dalam rumah sebagian memenuhi syarat yakni $5 \mathrm{~m}^{2}$ per orang.

Penelitian yang dilakukan Rahayu et al. (2018) di Kabupaten Konawe dengan responden yang berjumlah 632 orang mengemukakan bahwa ada hubungan antara kepadatan hunian dengan kejadian pen- yakit ISPA. Sejalan dengan ini, Dongky \& Kadrianti (2016) dengan pendekatan crosssectional juga menemukan bahwa kepadatan hunian berkontribusi besar terhadap terjadinya kejadian ISPA di di Kelurahan Takatidung Polewali Mandar. Sedangkan penelitian yang dilakukan Suswani (2018) dengan pendekatan casecontrol juga menemukan hubungan yang signifikan antara kepadatan hunian dengan insidensi terjadinya ISPA di wilayah kerja Puskesmas Ulugalung, Kabupaten Bantaeng.

Banyaknya jumlah keluarga yang menempati luas lantai tertentu dapat menyebabkan terjadinya kepadatan hunian. Luas lantai bangunan rumah dengan kategori sehat harus terpenuhi cukup bagi penghuninya, artinya jumlah anggota keluarga dalam satu rumah harus dikondisikan dengan luas lantai bangunan tersebut. Luas bangunan yang tidak sebanding dengan jumlah penghuninya akan menyebabkan terjadinya overcrowded. Luas lantai bangunan rumah sehat harus disesuaikan dengan jumlah penghuninya.

Kepadatan hunian rumah dapat menyebabkan penularan penyakit khususnya melalui udara semakin cepat. Rumah dengan kepadatan penghuni yang tinggi dapat menyebabkan sirkulasi udara tidak baik, pertukaran udara tidak lancar serta akan memperburuk kesehatan penghuni 
rumah jika apabila ventilasi rumah tidak dalam kondisi baik. Hal ini juga akan berbahaya apabila ada penghuni rumah yang mengalami gangguan pernafasan yang disebabkan oleh bakteri, virus, atau debu, yang akan menginfeksi anggota keluarga yang lain akibat menghirup udara yang sama dan sudah tercemar. Penularan penyakit pada penghuni akan semakin berisiko jika terjadi kepadatan penghuni dalam rumah.

Pada kondisi suhu tertentu agen penyebab penyakit infeksi pernafasan seperti virus dan bakteri akan lebih mudah untuk tumbuh. Demikian pula pada beberapa jenis polutan udara tertentu yang dapat bertahan pada lingkungan dengan suhu tertentu. Untuk mencegah timbulnya kasus kesakitan maka temperatur dalam rumah harus berkisar antara $18-20^{\circ} \mathrm{C}$ atau $18-30^{\circ} \mathrm{C}$.

Hasil menunjukkan bahwa (72.5\%) rumah responden memiliki suhu ruangan yang memenuhi syarat dan $(27.5 \%)$ rumah responden memiliki suhu ruangan yang tidak memenuhi syarat yang ditentukan apabila suhu ruangan berkisar $18-30^{\circ} \mathrm{C}$. Berdasarkan hasil observasi, suhu ruangan rumah responden memenuhi syarat karena sebagian besarnya memiliki suhu antara 18$30^{\circ} \mathrm{C}$.

Hasil penelitian ini menunjukkan hasil yang berbeda dengan hasil penelitian yang dilakukan oleh Silalahi \& Rumahorbo (2018) yang meneliti 80 remaja usia 12-18 tahun. Hasil penelitiannya menunjukkan bahwa suhu ruangan berpengaruh pada kejadian ISPA pada anak di Kabupaten Deli Serdang. Hasil penelitian lain dari Ikäheimo (2016) menemukan bahwa infeksi pernafasan HRV (human rhinovirus) akan mengalami meningkatkan risiko sebesar $8 \%$ setiap penurunan suhu $1^{\circ} \mathrm{C}$. Penurunan suhu selama beberapa hari akan meningkatkan risiko terjadinya infeksi terutama di musim dingin.

Kelembaban rumah yang tinggi akan meningkatkan kerentanan tubuh terhadap penyakit terutama penyakit infeksi serta akan mempengaruhi penurunan daya tahan tubuh penghuni rumah. Bakteri dapat bertahan hidup dalam kondisi yang lembap. Menurut Park (2020), kelembaban dianggap baik jika memenuhi $40-70 \%$ dan buruk jika kurang dari $40 \%$ atau lebih dari $70 \%$.

Hasil menunjukkan bahwa (67.5\%) rumah responden memiliki suhu ruangan yang memenuhi syarat dan $(32.5 \%)$ rumah responden memiliki suhu ruangan yang tidak memenuhi syarat yang ditentukan apabila kelembaban ruangan berkisar 40-70\%. Berdasarkan hasil observasi, kelembaban ruangan rumah responden memenuhi syarat karena sebagian besarnya memiliki kelembaban antara 40-70\%. Hal ini berbeda dengan penelitian yang dilakukan oleh Suharno et al. (2019) yang mengkaji faktor risiko dari kejadian ISPA dengan men- 
gobservasi kondisi fisik lingkungan rumah balita di wilayah kerja Puskemas Wawonasa, Kota Manado. Hasil penelitian menunjukkan bahwa terdapat hubungan antara kelembapan, dengan kejadian ISPA pada balita di wilayah kerja Puskesmas Wawonasa.

\section{KESIMPULAN}

Sebagian besar responden yang didiagnosis menderita ISPA memiliki luas ventilasi yang tidak memenuhi syarat $(66,3 \%)$. Hal ini dapat berakibat terganggunya sirkulasi udara yang pada akhirnya manusia dapat berpotensi kontak dengan mikroorganisme dalam ruang. Faktor higiene personal dan faktor lingkungan perumahan tetap menjadi perhatian masyarakat karena menjadi salah satu faktor yang berpotensi menyebabkan ISPA meskipun pada penelitian ini tidak menunjukkan hasil yang signifikan. Penelitian ini tidak mengkaji faktor gizi dan keadaan udara di sekitar rumah yang kemungkinan dapat menjadi penyebab utama kejadian penyakit ISPA.

\section{SARAN}

Masyarakat perlu memiliki kebiasaan untuk membuka jendela pada pagi hari agar sirkulasi udara dapat terjadi serta cahaya matahari dapat masuk. Hal ini akan bermanfaat dalam mengurangi kelembaban dalam rumah. Masyarakat juga diharapkan dapat menjaga kebersihan rumah terutama pada dinding dan lantai rumah, agar tidak menjadi tempat perkembangbiakan vektor dan bibit penyakit. Peneliti lain perlu mengembangkan penelitian ini dengan memperluas wilayah observasi di Kabupaten Gowa karena penyakit ini dalam beberapa tahun telah masuk dalam 10 besar penyakit yang sering diderita masyarakat yang ada di puskesmas Kabupaten Gowa

\section{DAFTAR PUSTAKA}

Adesanya, O. A., \& Chiao, C. (2016). A multilevel analysis of lifestyle variations in symptoms of acute respiratory infection among young children under five in Nigeria. BMC public health, 16(1), $\quad 880 . \quad \mathrm{http}: / /$ doi.org/10.1186/s12889-016-3565-0

Admasie, A., Kumie, A., \& Worku, A. (2018). Children under five from houses of unclean fuel sources and poorly ventilated houses have higher odds of suffering from acute respiratory infection in Wolaita-Sodo, southern Ethiopia: a case-control study. Journal of environmental and public health,2018. https:// doi.org/10.1155/2018/9320603

Bakaletz L. O. (2017). Viral-bacterial coinfections in the respiratory tract. Current opinion in microbiology, 35, 30-35. https:// doi.org/10.1016/j.mib.2016.11.003

Barnes, R., Blyth, C. C., De Klerk, N., Lee, W. H., Borland, M. L., Richmond, P., Lim, F. J., Fathima, P., \& Moore, H. C. (2019). Geographical disparities in emergency department presentations for acute respiratory infections and risk factors for presenting: a popula- 
tion-based cohort study of Western Australian children. BMJ open, 9(2). http://dx.doi.org/10.1136/bmjopen2018-025360

Barros, S. D., \& Yudhana, A. (2019). Physical Conditions Of House And Community Behavior Analysis Of Acute Respiratory Tract Infection In Working Region Central Public Health Soe City South East Central District. Journal of Global Research in Public Health, 4(2), 175-182. https:// www.jgrph.org/index.php/JGRPH/ article/view/49

Chandrawati, P. F., \& Alhabsyi, F. (2017). Hubungan Berat Badan Lahir Rendah terhadap Frekuensi Kejadian ISPA pada Balita Usia 1-4 Tahun. Saintika Medika: Jurnal Ilmu Kesehatan dan Kedokteran Keluarga, 10(1), 31-36. https://doi.org/10.22219/sm.v10i1.414 5

Davidson, J. A., \& Warren-Gash, C. (2019). Cardiovascular complications of acute respiratory infections: current research and future directions. Expert Review of Anti-infective Therapy, 17(2), 939-94.2 https://doi.org/10.1080/14787210.201 9.1689817

Devasia, J. T., Lakshminarayanan, S., \& Kar, S. S. (2020). How Modern Geographical Information Systems Based Mapping and Tracking Can Help to Combat Severe Acute Respiratory Syndrome Coronavirus 2 (SARSCoV-2) Pandemic around the World and India. International Journal of Health Systems and Implementation Research, 4(1), 30-54. https://ijhsir.ahsas-

pgichd.org/index.php/ijhsir/article/vie w/64

Dinas Kesehatan Kabupaten Gowa. (2016). Profil Kesehatan Kabupaten Gowa
Tahun 2016

Dongky, P., \& Kadrianti, K. (2016). Faktor Risiko Lingkungan Fisik Rumah dengan Kejadian ISPA Balita di Kelurahan Takatidung Polewali Mandar. Unnes Journal of Public Health, 5(4), 324-329. https://doi.org/10.15294/ujph.v5i4.13 962

Halder, A. K., Luby, S. P., Akhter, S., Ghosh, P. K., Johnston, R. B., \& Unicomb, L. (2017). Incidences and costs of illness for diarrhea and acute respiratory infections for children $<5$ years of age in rural Bangladesh. The American journal of tropical medicine and hygiene, 96(4), 953-960. https://doi.org/10.4269/ajtmh.16-0005

Harerimana, J. M., Nyirazinyoye, L., Thomson, D. R., \& Ntaganira, J. (2016). Social, economic and environmental risk factors for acute lower respiratory infections among children under five years of age in Rwanda. Archives of Public Health, 74(1), 19. https://doi.org/10.1186/s13690-0160132-1

Ikäheimo, T. M., Jaakkola, K., Jokelainen, J., Saukkoriipi, A., Roivainen, M., Juvonen, R., Vainio, O., \& Jaakkola, J. J. (2016). A decrease in temperature and humidity precedes human rhinovirus infections in a cold climate. Viruses, 8(9), 244. https://doi.org/10.3390/v8090244

Kementerian Kesehatan RI. (2019a). Laporan Nasional Riskesdas 2018. https://www.litbang.kemkes.go.id/lap oran-riset-kesehatan-dasar-riskesdas/

Kementerian Kesehatan RI. (2019b). Laporan Provinsi Sulawesi Selatan Riskesdas 2018. https://www.litbang.kemkes.go.id/lap oran-riset-kesehatan-dasar-riskesdas/ 
Khodr, Z. G., Bukowinski, A. T., Gumbs, G. R., \& Conlin, A. M. S. (2017). Tetanus, diphtheria, and acellular pertussis vaccination during pregnancy and reduced risk of infant acute respiratory infections. Vaccine, 35(42), 56035610.

https://doi.org/10.1016/j.vaccine.2017 .08 .041

Kim, J. C., Jung, H. S., \& Lee, S. (2019). Spatial mapping of the groundwater potential of the geum river basin using ensemble models based on remote sensing images. Remote Sensing, 11(19), 2285. https://doi.org/10.3390/rs11192285

Kurskaya, O., Ryabichenko, T., Leonova, N., Shi, W., Bi, H., Sharshov, K., Kazachkova, E., Sobolev, I., Prokopyeva, E., Kartseva, T., Alekseev, A., \& Alekseev, A. (2018). Viral etiology of acute respiratory infections in hospitalized children in Novosibirsk City, Russia (2013-2017). PloS one, 13(9). https://doi.org/10.1371/journal.pone.0 200117

Kyu, H. H., Pinho, C., Wagner, J. A., Brown, J. C., Bertozzi-Villa, A., Charlson, F. J., ... \& Fitzmaurice, C. (2016). Global and national burden of diseases and injuries among children and adolescents between 1990 and 2013: findings from the global burden of disease 2013 study. JAMA pediatrics, $170(3)$, 267-287. http://doi.org/10.1001/jamapediatrics. 2015.4276

Liu, L., Oza, S., Hogan, D., Chu, Y., Perin, J., Zhu, J., Lawn, J. E., Cousens, S., \& Black, R. E. (2016). Global, regional, and national causes of under-5 mortality in 2000-15: an updated systematic analysis with implications for the Sustainable Development Goals. The Lancet, 388(10063), 3027-3035. https://doi.org/10.1016/S0140-

\section{6(16)31593-8}

Mahendra, I. G. A. P., \& Farapti, F. (2018). The Relationship between Household Physical Condition with Incidence of Toddler's Acute Respiratory Infection in Surabaya. Jurnal Berkala Epidemiologi, 6(3), 227-235. http://dx.doi.org/10.20473/jbe.V6I320 18.227-235

Mayasari, E. (2017). Analisis Faktor Risiko Kejadian ISPA Ditinjau dari Status Rumah di Wilayah Kerja Puskesmas Kota Wilayah Utara Kota Kediri. IKESMA, 13(1). https://doi.org/10.19184/ikesma.v13i1 .7020

Musa, N., Gul, R., Mehmood, Y., \& Afridi, S. (2016). Frequency of Risk Factors Leading to Acute Respiratory Infections Among Children Under Two Year's Age and their Gender and Age Wise Comparison. Journal of Gandhara Medical and Dental Science, 3(01), 16-21. https://doi.org/10.37762/jgmds.301.43

Narmawan, N., Pangestika, Y. W., \& Tahiruddin, T. (2020). Studi Komparatif Pemberian Susu Formula dan ASI Ekslusif Terhadap Kejadian ISPA Bayi Umur 0-6 Bulan. Journal of Holistic Nursing Science, 7(2), 179-186. https://doi.org/10.31603/nursing.v7i2. 3129

Neto, A. S., Barbas, C. S., Simonis, F. D., Artigas-Raventós, A., Canet, J., Determann, R. M., ... \& Hiesmayr, M. (2016). Epidemiological characteristics, practice of ventilation, and clinical outcome in patients at risk of acute respiratory distress syndrome in intensive care units from 16 countries (PRoVENT): an international, multicentre, prospective study. The Lancet Respiratory Medicine, 4(11), 
882-893.

https://doi.org/10.1016/S22132600(16)30305-8

Nugroho, H. S. W. (2018). Risk Factors at Home on Acute Respiratory Infection (ARI) Incidence in Children Under Five in Sapuli Island, South Sulawesi. Indian Journal of Public Health Research \& Development, 9(6), 210214. http://dx.doi.org/10.5958/09765506.2018.00551.X

Okari, M. T. (2019). Public Health Implications Of The Housing, Water And Sanitation Conditions In Kaburini Slum Of Kakamega Town, Kenya (Doctoral dissertation, University Of Nairobi). http://erepository.uonbi.ac.ke/handle/ $11295 / 108848$

Padmonobo, H., Setiani, O., \& Joko, T. (2012). Hubungan faktor-faktor lingkungan fisik rumah dengan kejadian pneumonia pada balita di wilayah kerja Puskesmas Jatibarang Kabupaten Brebes. Jurnal Kesehatan Lingkungan Indonesia, 11(2), 194-198. https://doi.org/10.14710/jkli.11.2.194 $-198$

Park, J. E., Son, W. S., Ryu, Y., Choi, S. B., Kwon, O., \& Ahn, I. (2020). Effects of temperature, humidity, and diurnal temperature range on influenza incidence in a temperate region. Influenza and other respiratory viruses, 14(1), 11-18. https://doi.org/10.1111/irv.12682

Putri, P., \& Manutu, M. R. (2019). Pengaruh lingkungan fisik rumah terhadap kejadian ISPA pada balita di Kecamatan Ciwandan Kota Cilegon periode Juli - Agustus 2016. Tarumanagara Medical Journal, 1(2), 389-394.

http://dx.doi.org/10.24912/tmj.v1i2.38
42

Rahayu, I., Yuniar, N., \& Fachlevy, A. F. (2019). Faktor yang Berhubungan dengan Kejadian Penyakit Ispa pada Balita di Wilayah Kerja Puskesmas Soropia Kabupaten Konawe Tahun 2017. Jurnal Ilmiah Mahasiswa Kesehatan Masyarakat, 3(3). http://ojs.uho.ac.id/index.php/JIMKE SMAS/article/download/5333/3966

Ratnaningsih, T., \& Lusiana, E. (2020). Relationship Between Cleanliness of the Home Environment with Incidence of Acute Respiratory Infections among Children Under Five Years. International Journal of Nursing and Health Services (IJNHS), 3(2), 727-737. https://doi.org/10.18502/kls.v4i4.2312

Selvaraj, K., Chinnakali, P., Majumdar, A., \& Krishnan, I. (2014). Acute respiratory infections among under-5 children in India: a situational analysis. Journal of natural science, biology and medicine, 5(1), 15 . https://doi.org/10.4103/09769668.127275

Silalahi, N., \& Rumahorbo, J. P. (2018). Analisis Korelasi Koefisien Kontingensi Untuk Mengetahui Besarnya Hubungan Kejadian ISPA Pada Remaja. Jurnal Penelitian Kesmasy, 1(1), 20-26. http://ejournal.delihusada.ac.id/index. php/JPKSY/article/view/38

Simoes, E. A. F., Cherian, T., Chow, J., Shahid-Salles, S. A., Laxminarayan, R., \& John, T. J. (2006). Acute Respiratory Infections in Children. (D. T. Jamison, J. G. Breman, A. R. Measham, G. Alleyne, M. Claeson, D. B. Evans, P. Jha, A. Mills, \& P. Musgrove (eds.); 2nd ed.). The International Bank for Reconstruction and Development. https:// 
pubmed.ncbi.nlm.nih.gov/21250360/

Suabey, S. (2020). Hubungan sanitasi fisik rumah dengan kejadian infeksi saluran pernafasan akut masyarakat Kampung Anelak Distrik Siepkosi Kabupaten Jayawijaya. Jurnal Keperawatan Tropis Papua, 3(1), 157-160. https://doi.org/10.47539/jktp.v3i1.97

Suharno, I., Akili, R. H., \& Boky, H. B. (2019). Hubungan Kondisi Fisik Lingkungan Rumah Dengan Kejadian Ispa Pada Balita Di Wilayah Kerja Puskesmas Wawonasa Kota Manado. KESMAS, 8(4).

https://ejournal.unsrat.ac.id/index.ph p/kesmas/article/view/23970

Suswani, A., \& Aszrul, A. B. (2018). Hubungan Kepadatan Hunian Dan Ventilasi Rumah Dengan Kejadian Ispa Pada Balita Di Wilayah Kerja Puskesmas Ulugalung, Kecamatan Eremerasa Kabupaten Bantaeng. Jurnal Kesehatan Panrita Husada, 3(1), 1-12. https://doi.org/10.37362/jkph.v3i1.1 69

Tazinya, A. A., Halle-Ekane, G. E., Mbuagbaw, L. T., Abanda, M., Atashili, J., \& Obama, M. T. (2018). Risk factors for acute respiratory infections in children under five years attending the
Bamenda Regional Hospital in Cameroon. BMC Pulmonary Medicine, $18(1)$, 7. https://doi.org/10.1186/s12890-0180579-7

Walker, C., Rudan, I., Liu, L., Nair, H., Theodoratou, E., Bhutta, Z. A., O'Brien, K. L., Campbell, H., \& Black, R. E. (2013). Global burden of childhood pneumonia and diarrhoea. Lancet (London, England), 381(9875), 14051416. https://doi.org/10.1016/S01406736(13)60222-6

Zhu, S., Jenkins, S., Addo, K., Heidarinejad, M., Romo, S. A., Layne, A., ... \& Adenaiye, O. O. (2020). Ventilation and laboratory confirmed acute respiratory infection (ARI) rates in college residence halls in College Park, Maryland. Environment international, 137, 105537. https://doi.org/10.1016/j.envint.2020. 105537

Zulaikhah, S. T., Soegeng, P., \& Sumarawati, T. (2017). Risk Factors of Acute Respiratory Infections in Practice Area for Community of Medical Students in Semarang. Kesmas: National Public Health Journal, 11(4), 192. http://doi.org/10.21109/kesmas.v11i4. 1281 